\title{
Editorial: Soil Evolution and Sustainability
}

\author{
Sophie Cornu ${ }^{1 \star}$, David Montagne ${ }^{2}$, Christina Bogner ${ }^{3}$ and Luca Montanarella ${ }^{4}$ \\ ${ }^{1}$ Aix Marseille Univ., CNRS, IRD, INRAE, Coll France, CEREGE, Aix-en-Provence, France, ${ }^{2}$ Université Paris-Saclay, INRAE, \\ AgroParisTech, UMR ECOSYS, Thiverval-Grignon, France, ${ }^{3}$ Ecosystem Research, Institute of Geography, University of \\ Cologne, Cologne, Germany, ${ }^{4}$ Joint Research Centre, European Commission, Ispra, Italy
}

Keywords: pedogenesis, soil services, soil protection, global change, soil quality

\section{Editorial on the Research Topic}

\section{Soil Evolution and Sustainability}

Soils contribute to major ecosystem services (as defined by the Millennium Ecosystem Assessment, 2005) by playing a crucial role in provisioning food and fibers, regulating water and geochemical cycles and delivering cultural services. Soils are rich in biodiversity and provide the habitat for a large number of species, many yet to be fully described. Due to this central role of soils in the delivery of ecosystem goods and services, the Soil Security concept was introduced to help Soil Science to be translated into policy guidelines for sustainable development and to be included in the Global Agenda (Koch et al., 2013; Bouma et al., 2019). Soils are indeed keys for reaching many of the Sustainable Development Goals (SDGs) by 2030. Especially SDG 2, related to fighting hunger and achieving food security, as well as SDG 15, on protecting the terrestrial environment

OPEN ACCESS

Edited by:

Maria Luz Cayuela

Spanish National Research Council (CSIC), Spain

Reviewed by:

Francoise Watteau,

Université de Lorraine, France

*Correspondence:

Sophie Cornu sophie.cornu@inrae.fr

Specialty section:

This article was submitted to Soil Processes,

a section of the journal

Frontiers in Environmental Science

Received: 18 September 2019

Accepted: 19 February 2020

Published: 10 March 2020

Citation:

Cornu S, Montagne D, Bogner C and Montanarella L (2020) Editorial: Soil

Evolution and Sustainability.

Front. Environ. Sci. 8:23.

doi: 10.3389/fenvs.2020.00023 for future generations, imply the application of sustainable soil management at the global scale. The IPCC report on Climate Change and Land names land and soil degradation through erosion, organic matter decline, contamination, soil sealing, compaction, loss of biodiversity or salinization as key challenges related to land use change (IPCC, 2019). Achieving food security and the elimination of hunger while simultaneously protecting our terrestrial environment is a great challenge that requires extensive, multidisciplinary research, including also human and social sciences: economists, geographers, sociologists, and urban planners.

The need is urgent. Global changes that include climate change, land cover changes due to the ever increasing human pressure on land or changes in agricultural management practices acting in either a synergic or antagonistic way have recently been shown to induce changes in all of the soil characteristics, including the so-called "inherent" soil properties, on decadal to century time scales (Guo and Gifford, 2002; Guo et al., 2010; Cornu et al., 2012; Boizard et al., 2013). The direction, intensity and spatial distribution of these soil changes and their consequences on the delivery of soil services and finally on human well-being remain however largely unknown.

The most commonly studied evolutions of soil characteristics are organic carbon, $\mathrm{pH}$, and bulk density (Fell et al.; Asabere et al.; Yemefack et al.; de Tombeur et al., among others) but also soil structure (Fell et al.) or soil production (Egli et al.). Soil differentiation and soil mineralogy also evolve (Cornu et al., 2012; Montagne et al., 2016). The time scales considered range from 7 years (de Tombeur et al.) up to 1,000,000 years (Egli et al.). Changes are evidenced in very contrasted soil types, from Alpine environments (Egli et al.) to tropical soils (Asabere et al.; Yemefack et al.).

Agricultural activities may lead to either the improvement or the deterioration of soil services (biomass production, carbon sequestration, climate regulation, nutrient recycling, and water purification, etc.) emerging from the evolution of soil characteristics. While examples of soil deterioration due to human activities are extremely frequent in the literature, examples of practices inducing soil recovery are less common. Fell et al. propose and analyse the use of cover-crop and 
tillage to remediate compacted orchards, while Asabere et al. evaluate the potential and drawbacks of urban waste management in agriculture to increase the fertility of urban soils in Ghana. Adequate soil management appears thus as a powerful sustainability lever as (i) managed soil recovery may be much faster than natural recovery (see the rates provided by Fell et al. and Yemefack et al., for managed and natural recovery, respectively) and as (ii) adequate soil management may result in a simultaneous increase in food security or be particularly helpful to recycle organic wastes or mitigate climate change (Asabere et al.). Thus, understanding and projecting the impact of land use and management on soils are a prerequisite for sustainable development.

Modeling is a key tool to help in predicting future states of soils and thus their sustainability. Two examples of modeling approaches are presented in this issue. Simple empirical equations are proposed by Yemefack et al. to help decision makers in assessing soil quality evolution after land use change. Since future combinations of climate, land use and soil type are unprecedented, purely empirical or statistical predictionsdespite being highly appropriate for applied purposes and decision makers-may not be relevant for predicting future states of soils on a long term scale (century or more). Alternatively,

\section{REFERENCES}

Boizard, H., Yoon, S. W., Leonard, J., Lheureux, S., Cousin, I., RogerEstrade, J., et al. (2013). Using a morphological approach to evaluate the effect of traffic and weather conditions on the structure of a loamy soil in reduced tillage. Soil Tillage Res. 127, 34-44. doi: 10.1016/j.still.2012. 04.007

Bouma, J., Montanarella, L., and Evanylo, G. (2019). The challenge for the soil science community to contribute to the implementation of the UN Sustainable Development Goals. Soil Use Manage. 35, 538-546. doi: 10.1111/sum. 12518

Cornu, S., Montagne, D., Hubert, F., Barré, P., and Caner, L., (2012). Evidence of short-term clay evolution in soils under human impact. C. R. Geosci. 344, 747-757. doi: 10.1016/j.crte.2012.09.005

Guo, J. H., Liu, X. J., Zhang, Y., Shen, J. L., Han, W. X., Zhang, W. F., et al. (2010). Significant acidification in major Chinese croplands. Science 327, 1008-1010. doi: $10.1126 /$ science. 1182570

Guo, L. B., and Gifford, R. M. (2002). Soil carbon stocks and land use change: a meta analysis. Glob. Chang. Biol. 8, 345-360. doi: $10.1046 /$ j.1354-1013.2002.00486.x

IPCC (2019). Special Report on Climate Change, Desertification, Land Degradation, Sustainable Land Management, Food Security, and Greenhouse gas fluxes in Terrestrial Ecosystems. IPCC. deterministic modeling that explicitly considers the fluxes of solid constituents, solute and water transfers, agricultural practices, and the feedback loops between soil functioning and soil structure could simulate the effect of changes in climate or human practices on soils (Samouëlian et al., 2012). An example of this is proposed by Egli et al. to predict soil production from solute transfer on the long term (from a few tens to a million of years). This second approach considers interactions and retroactions between physical and chemical processes. As empirical equations are rather complex to use, they should therefore be applied on the result provided by the model to help decision makers in soil management. Far from opposing the two approaches, we consider them as highly complementary in addition to existing soil databases and long-term soil monitoring sites where the impact of land use change and management on the evolution of soil characteristics should be followed on a considerably larger set of characteristics than organic carbon in order to feed, calibrate or validate empirical or deterministic models.

\section{AUTHOR CONTRIBUTIONS}

All authors have contributed to the writing of the present editorial after having contributing to the Research Topic.

Koch, A., McBratney, A., Adams, M., Field, D., Hill, R., Crawford, J., et al. (2013). Soil security: solving the global soil crisis. Glob. Policy 4, 434-441. doi: 10.1111/1758-5899.12096

Millennium Ecosystem Assessment (2005). World Resources Institute. Washington, DC, 86.

Montagne, D., Cousin, I., and Cornu, S., (2016). Changes in the pathway and the intensity of albic material genesis: role of agricultural practices. Geoderma 268, 156-164. doi: 10.1016/j.geoderma.2016.01.019

Samouëlian, A., Finke, P., Goddéris, Y., and Cornu, S., (2012). "Chapter 19: Hydrologic information in pedologic models," in Hydropedology, ed H. Lin (Boston, MA: Academic Press), 595-636.

Conflict of Interest: The authors declare that the research was conducted in the absence of any commercial or financial relationships that could be construed as a potential conflict of interest.

Copyright (c) 2020 Cornu, Montagne, Bogner and Montanarella. This is an openaccess article distributed under the terms of the Creative Commons Attribution License (CC BY). The use, distribution or reproduction in other forums is permitted, provided the original author(s) and the copyright owner(s) are credited and that the original publication in this journal is cited, in accordance with accepted academic practice. No use, distribution or reproduction is permitted which does not comply with these terms. 